\title{
ПОДГОТОВКА СПЕЦИАЛИСТОВ БПЛА В ГОСУДАРСТВЕННОМ ЦЕНТРЕ БЕСПИЛОТНОЙ АВИАЦИИ МО РФ
}

\section{TRAINING OF UAV SPECIALISTS IN THE STATE UNMANNED AVIATION CENTER OF THE RF MOD}

\section{Lezhnev}

Summary: Unmanned aerial vehicles are used in modern solutions to various tasks, and the issue of training competent operators who know their business is an acute issue.

Keywords: unmanned aerial vehicles, drones, UAVs, State Center of the Russian Ministry of Defense, specialists, operators, management, training.

\author{
Лежнев Дмитрий Сергеевич \\ Филиал Военно-учебного научного чентра Военно- \\ воздушных сил «Военно-воздушная академия» \\ в г. Челябинске \\ lezhnev.d.s@mail.ru
}

Аннотация: В современных условиях для решения различных задач используются беспилотные летательные аппараты, вследствие этого остро стоит вопрос о подготовке грамотных операторов, знающих свое дело.

Ключевые слова: беспилотные летательные аппараты, дроны, БПЛА, Государственный центр Минобороны России, специалисты, операторы, управление, подготовка.
$\mathrm{B}$ армиях иностранных государств ведутся интенсивные работы по принятию на вооружение различных типов беспилотных летательных аппаратов (БПЛА) и робототехнических средств, которые рассматриваются руководством вооруженных сил США и стран - членов блока НАТО в качестве одного их важнейших средств повышения боевых возможностей вооруженных сил и расширения перечня успешно выполняемых боевых задач на новом уровне при существенном снижении потерь личного состава, а также дорогостоящей пилотируемой авиационной техники в ходе ведения боевых действий. Для управления БПЛА и робототехническими средствами в иностранных армиях разрабатываются специальные системы управления, от качества функционирования которых во многом зависит эффективность применения БПЛА [3]. В этих условиях одной из актуальных становится задача подготовки специалистов БПЛА для успешного решения поставленных задач.

Развитие беспилотной авиации в России на данный момент находится на подъеме. Проанализировав опыт стран НАТО и привнеся в него свои новшества и нововведения, в Министерстве обороны Российской Федерации сумели добиться того, что опыт и тактику использования беспилотников теперь начали перенимать и в нашей стране. Так с 2009 года в г. Коломне Московской области успешно работает 924-й Государственный центр беспилотной авиации МО РФ, который занимается изучением теории и практики применения БПЛА и подготовкой специалистов в данной сфере. В нем осуществляется обучение специалистов для обслуживания и работы с комплексами БПЛА как отечественных, так и зарубежных разработок. Также центр беспилотной авиации является базой для испытания всех видов беспилотников перед принятием их на вооружение.

Сейчас в центр подготовки входят следующие подразделения:

- подразделение управления центром;

- исследовательское подразделение, отвечающее за войсковые испытания всех видов БПЛА;

- курсы подготовки и переподготовки всех специалистов обслуживания комплексов;

- две учебных эскадрильи БПЛА.

В Минобороны России уделяется повышенное внимание на совершенствование методов и способов причинения беспилотников. Стоит отметить, что в данной сфере проделан значительный рывок. По данным на 2011 год в Вооруженных силах Российской Федерации было 180 беспилотных систем, в 2015 году их число возросло почти в 10 раз [5]. К тому же, опыт полученный в Сирийской Арабской Республике при выполнении боевых задач, и анализ боевых действий осени 2021 года в зоне вооруженного конфликта в Нагорном Карабахе показали, что использование БПЛА позволяет достичь значительных результатов. В настоящее время в каждом военном округе созданы роты беспилотной авиации. В Государственном центре беспилотной авиации не только подготавливают операторов дронов, но и занимаются изучением теоретических вопросов применения БПЛА, а также осваивают новые виды беспилотной техники.

На сегодняшний день, по мере увеличения задач, которые призваны осуществлять дроны, актуален вопрос о необходимости обучения грамотных и толковых операторов. Именно с этой целью создан Государственный центр. Помимо этого, он осуществляет и другие задачи: 
- научные исследования;

- ликвидация последствий ЧС;

- воздушная разведка;

- проведение войсковых испытаний комплексов с БПЛА до их принятия на вооружение.

В ближайшем будущем предполагается обеспечение Государственного центра автоматизированной информационно-обучающей системой, а также образование в военных округах филиалов данного центра. В скором времени, не считая военнослужащих Министерства обороны будут обучаться специалисты из других ведомств, таких как Министерство по делам гражданской обороны, чрезвычайным ситуациям и ликвидации последствий стихийных бедствий, Министерство внутренних дел и Федеральная служба безопасности.

Американские военные при подготовке операторов комплексов БЛА раньше отбирали кандидатов из числа бывших пилотов. В настоящее же время обучают самых продвинутых геймеров, но при этом появилась масса проблем, включая морально-физические. Это в первую очередь касается операторов ударных комплексов, чьи «подопечные» работают в реальных боевых условиях, нанося удары по противнику [3].

В Государственном центре пошли по традиционному пути. Оператор непосредственного управления полетом самолета, готовится из числа людей, имеющих опыт управления летательными аппаратами.

В центре беспилотной авиации проходят подготовку:

- командный состав подразделений беспилотной авиации;

- руководители полетов;

- операторы обработки информации;

- старшие операторы по управлению БПЛА;

- инженерно-технический состав групп авиационного и радиоэлектронного обеспечения;

- техники и механики комплексов с БПЛА;

- младшие авиационные специалисты.

В Государственном центре обучаются только военнослужащие контрактной службы, которые имеют профессиональное образование. Перед тем как получить направление в данный центр, военнослужащему для сначала необходимо пройти необходимые экзамены в воинской части, в которой он проходит службу.

Изначально курсанты центра проходят теоретический курс подготовки, после чего допускаются к экзаменам, также они приобретают необходимый опыт в управлении БПЛА на тренажной аппаратуре и после получения определенных допусков уже принимаются за практические занятия. Как оказалось, обучение в данном центре далеко не простое. Уже в первые недели об- учения 10-15 процентов из числа поступивших не могут успешно сдать экзамены.

На теоретических занятиях курсанты занимаются тактической и специальной подготовкой, топографией, связью. Помимо этого, будущие операторы дронов должны уверенно пользоваться компьютером и иметь базовые знания при работе с ним. Наибольший акцент уделяется на изучения технической составляющей беспилотников.

Во время практики на тактических стрельбищах осваивается тот материал, который изучался на теории. Под руководством инструкторского состава курсанты пробуют самостоятельно осуществлять запуск беспилотников в воздух с дальнейшим выполнением поставленных учебных задач. Стоит отметить, что непогода на никак не влияет на проведение практических занятий, дронов можно запускать и в дождь, и в снег.

В центре несколько курсов обучения, они зависят от того, какой тип БПЛА хочет освоить курсант. Это могут быть комплексы ближнего действия и малой дальности, типа БПЛА «Гранат» в различных модификациях, а также «Застава», «Элерон», и др. [2], обучение на которые займет 2,5 месяца. Обучение на комплексы среднего действия, типа беспилотника «Форпост» [2], уже займет в среднем 4 месяца. По завершению обучения военнослужащие отправляются обратно в свои воинские части.

В действительности, на сегодняшний день очень многие хотят пройти обучение в Государственном центре беспилотной авиации. Это обусловлено наличием в центре преподавателей, имеющих большой практический опыт, и новейшей учебной базы. Центр работает не только на обучение курсантов, специалисты данного центра занимаются созданием новых пособий по применению комплексов с БПЛА. К тому же тактика применения беспилотной авиации нашего государства признается сейчас лучшей в мире. Это заслуга в первую очередь руководящего состава центра, которое смогло создать особый объект, способный осуществлять обучение и подготовку специалистов мирового уровня.

Безусловно в создании боевых беспилотников Россия пока уступает некоторым государствам. Во времена Советского Союза данное направление считалось одним из наиважнейших, и наша страна была на лидирующих строчках, но в 90-е годы данная отрасль значительно сдала позиции [5]. Сегодня же промышленность в направлении беспилотной авиации старается наверстать упущенное.

Разрабатываются новые тяжелые беспилотники, на которые могут прикреплять ударное вооружение, а также создаются БПЛА вертолетного типа [2]. Дроны отечественного производства могут уверенно соперничать 
с ведущим моделям иностранных государств, они нисколько не уступают по эффективности ведения воздушной разведки, продолжительности и дальности полета, выполнению поставленных задач.

Из вышесказанного следует, что БПЛА - пожалуй, одно из самых ярких и впечатляющих технических достижений современных инновационных систем. Дальнейшее расширение функционала беспилотников лежит в направлении повышения их автономности - необходимы полностью автономные устройства, передвигающиеся в соответствии с заданной программой и обладающие большим спектром действий при контакте с человеком, который выступает потребителем услуг, предоставляемых дронами [4]. Наиболее часто БПлА применяются военными организациями, но также они могут быть полезны и в обыденной жизни, например, для съемок фильмов, картографических и метеорологических съемок, в спасательных операциях, при тушении пожаров, в исследовательских и научных целях и во многом другом. Многие страны уже имеют беспилотные системы на службе в военно-воздушных силах. Сегодня дроны применяются широко, а в будущем ожидается повышение спроса на них и наверняка расширение сферы их применения [1].

Желание человека летать возникло уже очень давно, и сейчас, когда люди не только поднялись в небо, но и смогли выйти в космос, деятельность, связанная с разработкой БПЛА и обеспечением полетов, стали одними из самых динамично развивающихся и перспективных.

\section{ЛИТЕРАТУРА}

1. Василин, Н.Я. Беспилотные летательные аппараты. - М.: Попурри, 2012. - 272 с.

2. Владимиров Л.А. Атака из поднебесья. Обзор современных беспилотников. Журнал «Аэрокосмическое обозрение» №5 2011. С.15-17.

3. Кондратьев А. Перспективы развития и применения беспилотных и роботизированных средств вооруженной борьбы в ВС ведущих зарубежных стран. Зарубежное военное обозрение №5, 2011. С. 14-21.

4. Панков С.Е. Роль военных технологий в развитии системы вооружения Вооруженных Сил Российской Федерации [Электронный ресурс]: Управление перспективных межвидовых исследований и специальных проектов Министерства обороны Российской Федерации. - Режим доступа: http://federalbook.ru/files/OPK/Soderjanie/OPK10/III/Pankov.pdf. - (Дата обращения: 28.03.2021).

5. Юферев С. Перспективы развития российских БПЛА [Электронный ресурс] // Информационно-новостной портал ARMY MAN. INF0. - Режим доступа: http://armyman.info/stati/15140-perspektivy-razvitiya-rossiyskih-bpla.html. - (Дата обращения: 28.03.2021).

(c) Лежнев Дмитрий Сергеевич (lezhnev.d.s@mail.ru). 